\title{
Development of Scientific-Based Electronic Science Modules to Improve Student Learning Outcomes in Knowledge Aspects During the Covid-19 Pandemic
}

\author{
Alifia Kurnia ${ }^{1}$ Sukarmin Sukarmin ${ }^{2 *}$, Widha Sunarno ${ }^{3}$ \\ 1,2,3 Universitas Sebelas Maret \\ *Corresponding author. Email: *sukarmin67@staff.uns.ac.id
}

\begin{abstract}
This study aimed to determine the feasibility and effectiveness of scientific-based science modules on vibration and wave materials to improve learning outcomes of knowledge aspects. This type of research is Research and Development which uses a 4D model which includes define, design, development, and distribute. Data collection techniques using questionnaires and tests. Data analysis used descriptive analysis to determine the feasibility of the module and the Mann-WhitneyU test to find out the difference in the average posttest value in the experimental class and the control class. The module effectiveness test involved 60 class VIII students. The results of the study indicate that the developed module is included in the very good category in terms of the feasibility of the quality of the content/material based on the assessment of experts, practitioners, and colleagues. The learning outcomes of the experimental class are better than the control class. This is based on descriptive analysis, the posttest score of the experimental class is higher than the control class and the results of the Mann-WhitneyU test indicate that there is a significant difference between the experimental class and the control class.
\end{abstract}

Keywords: Development, E-Module, Scientific, Knowledge Aspect

\section{INTRODUCTION}

The Covid-19 pandemic has changed various aspects of human life, especially in the education aspect, which requires all elements to remain active in the classroom even though online. The Covid-19 pandemic urges the implementation of distance education which has never been carried out before (Sun et al., 2020) for all elements of education, that is teachers, students and parents. Considering that during the pandemic, time, location and distance are the main problems today (Kusuma and Hamidah, 2020), distance learning is a solution to overcome difficulties in implementing direct learning. The implementation of Distance Education is different from the conditions during learning before the pandemic (Asmuni, 2020; Basar et al., 2021; Yoga Purandina \& Astra Winaya, 2020). The online learning process currently makes students less understanding of the material (Malyana, 2020). The pandemic urges adaptation and innovation related to the use of existing technology to support the learning process (Ahmed et al., 2020). Although facilities such as computers or laptops are already owned by teachers, teachers cannot develop an electronic book (Nakayama, M \& Yamamoto., 2006; Szép, 2017).

The results of observations in schools indicate that the problem in the learning process is the limitation of learning media, there are two learning media used in science learning in this junior high school, namely books from the Ministry of Education and from Subject Teachers Organization. However, this Subject Teachers Organization module only contains short material and practice questions such as student activity sheets. This makes students sometimes still have difficulty understanding a given material, especially in the conditions of Distance Learning.

Learning media is anything that can be used as a tool in the learning process. Teaching materials have a very vital role in the aspect of education, one of which is in learning because the teaching materials themselves can be integrated with the situation and conditions of students, student characteristics, and also the material 
delivered in the learning process. This is shows that the module has an important role in the learning process (Mustika, 2015). Efforts can be made to improve mastery of the material, one of which is the use of additional learning media, namely modules. The use of electronic learning modules so far has not been carried out optimally so that it causes a lack of student interest in learning. The learning module is a form of teaching material, containing specific material that is arranged operationally, systematically, and directed that is used by students accompanied by a guide to its use for teachers. (Depdiknas, 2008). The use of electronic modules is also expected to make it easier for students to study independently given the current Covid-19 pandemic which make students have to study from their home.

Another problem is that the learning outcomes of class VIII students in science subjects have not yet reached the Kriteria Ketuntasan Minimal or KKM (Minimum Completeness Criteria). It is proven by the KKM score of 75 with a total of 30 students, the percentage results of $10 \%$ percent have reached the KKM, while $90 \%$ of students have not reached the minimum criteria.

The aspect of knowledge is one of the psychological aspects that really need to be understood by an educator because the nature of learning organized by educators must be adjusted to the level of cognitive development of children. According to Darouich cited by Hasan Basri, the cognitive system itself is a complex processing device in humans that is able to acquire, preserve, process and transmit information (Basri, 2018). Cognitive development focuses on thinking skills, including learning, problem solving, rationality, and memory. Students are objects that are directly related to the learning process, so cognitive development will determine student success in school. As according to Zainiyati (2017) that from the beginning the cognitive taxonomy on educational goals was designed to facilitate the process of designing learning evaluations.

One of the solutions to fix these problems is to use a scientific-based electronic science module. The module is a learning tool that contains material, methods, and how to evaluate which is designed in a systematic and interesting way to get the expected competencies according tonthe level of complexity. The module is structured with the aim of helping students learn something, making it easier for educators to teach something and making learning activities more interesting (Depdiknas, 2008). The independent learning module will help students during the Covid-19 pandemic so that students can learn independently and not depend on other parties. (Mustaji, 2008). According to Hosnann (2014:34) the scientific approach is a learning process designed so that students can actively construct concepts, laws or principles through the stages of observing, analyzing, analyzing, collecting data, drawing conclusions and communicating the concepts found.

Electronic modules are defined as interactive teaching materials that are designed in various forms so that they are not monotonous, so that they can bring students' interest in learning (Imansari \& Sunaryantiningsih, 2017; Winatha et al., 2018). Electronic modules have the advantage that they can increase the effectiveness and flexibility of learning (Santosa, 2011; Surjono, 2009), not related to time and location (Gozali \& Lo, 2012; Suwasono, 2013), can make the learning process interesting and not get bored quickly because the module Electronic devices are equipped with various pictures, videos, and many interesting features that can increase learning motivation (Depdiknas, 2008).

Research by Ditasari (2013) shows the results that the development of an integrated science module can improve student learning outcomes on environmental impact materials. Furthermore, research by Idrus (2020) shows that science-based learning can increase learning activities and improve student learning outcomes on the senses. Research by Putri (2021) shows the results that the use of electronic modules can increase learning independence during a pandemic on water cycle material. Based on the description above, this study aimed to determine the effect of the implementation of the Scientific-Based Module in improving learning outcomes of knowledge on vibration and wavenmaterial.

\section{RESEARCH METHOD}

This study uses the Research and Development method, which is a research method used to produce certain products, and test the effectiveness of these products. This research development process refers to the model by Thiagarajan which consists of 4D namely define, design, development andndisseminate. The product developed in this research is a electronic modul with scientific based on vibration and wave materials The study was conducted at Junior High School 15 Surakarta with 6 students as the subject of class VIII D for a limited scale trial, 30 students of class VIII $\mathrm{H}$ as the control class and 30 students of class VIII E as the experimental class. The analysis to determine the equivalence of students' knowledge of the two classes before the learning was carried out was tested using SPSS 20 for windows which began with a prerequisite test, namely the normality test, homogeneity test, and the Mann-WhitneyU test using the previous test scores.

The steps in this research are first collecting information, designing the product, revising the product, product testing on a limited scale, revise the product 
phase II, testing the product design on a broad scale, revise the product design phase III, and producing the product. Sources of data for this research include: data on the feasibility assessment of the module by experts using an instrument in the form of a questionnaire containing an assessment of the feasibility of the developed module, data on responses to the use of the module by teachers and students in the form of a questionnaire, and data on students' creative thinking abilities measured by tests. Before the test questions are used, the test questions that have been prepared are tested first. The quality of the measuring instrument for learning outcomes in the knowledge aspect is determined by several factors, including: reliability, difficulty level, and discriminatory power.. (Azwar, 2000).

\section{RESULT AND DISCUSSION}

\subsection{Module Development Proses}

The teaching material developed by the researcher is an electronic module. The reason the researchers chose to develop an electronic module is because the module can activate students in learning activities. In addition, the Covid19 pandemic condition requires students to study from home so that with the module students can learn on their own without having to depend on the teacher, so the teacher's role is only as a facilitator. If there is material that students do not understand, students can directly ask the teacher about the material.

The module developed by the researcher has scientific-based characteristics. Researchers choose electronic modules with a scientific basis so that students' creative thinking skills develop. So it is not only students' knowledge that develops but students' skills must also develop. Creative thinking skills is one of the cognitive components of students that can support their success. Creative thinking is a mental activity that is used to build new ideas or ideas (Siswono, 2008).

The materials selected in this module are vibrations and waves. This theme was chosen because the achievement of the national examination for vibration and wave material at Junior High School 15 Surakarta showed low results. In addition, the results of the analysis of the daily test data for class VIII students in 2019/2020 showed that the vibration and wave material had low student mastery and allowed for follow-up.

The development stage begins with the initial draft of the module that has been compiled and then validated by experts, including media expert, material expert, linguists, and learning expert. Based on suggestions from learning expert validators, material expert validators, language expert validators, and media expert validators, the following module improvements are made: a) Cover page, on the cover page consists of the following components: (1) module title, namely the Scientific-based Science Module ; (2) Vibration and Wave material; (3) Pictures/illustrations related to vibrations and waves; (4) Targets/users are students of SMP/MTs class VIII; (5) types of modules, namely student modules/supplementary teacher modules; (6) Name of module maker; b) Preface, containing information about the role of the Science-based SMP science module in the learning process as well as a brief explanation of the scope of the module content, in addition to the introduction there is a description of the identity of the module compiler and validator; c) Table of Contents, containing the parts or components of the module which is equipped with page numbers; d) List of Figures, containing image names, image numbers and image pages, e) List of tables, containing table names, table numbers, and table pages; f) The module profile contains information about the module parts; g) glossary, containing a list of important terms along with their explanations; h) introduction, containing Core Competencies, Basic Competencies, Indicators, module descriptions, implementation time, instructions for using modules and a scientific approach matrix with aspects of creative thinking abilities; i) Map of the position of the material, the position of the material from the module among other materials; j) Concept Map, contains an explanation of the concepts in the material used.

In part two, it consists of components of learning activities which contain: (1) the title page of the learning activities; (2) scientific-based learning activities; (3) presentation rules (4) material notes and sample questions; (5); (6) did you know?, which contains interesting facts related to the material; (7) practice questions, in the form of practice questions regarding the material being studied. In the third part, namely the closing which contains (1) a bibliography, containing bibliographical references used as a reference for compiling the module and (2) a biography of the author. The results of the improvement of the module from the validation of the module by several experts became the draft II of the module.

The validation process produces notes that are considered for revision. The results of the validation process is a draft module that is ready for further field testing. The results of the validation of learning experts, material experts, linguists, media experts, education practitioners, and colleagues for the junior high school science module in general, the feasibility of the developed module is "Very Valid" so that the conclusion of the validation is feasible to use. The summary of the Expert Validation results can be seen in Table 1.

The trials in this study were conducted twice, namely limited-scale trials and broad-scale trials. Limited trial involving 2 science teachers and 6 students 
of class VIII D consisting of 3 high-ability students and 3 low-ability students. Taking students on limited trials with different levels of cognitive mastery is intended so that the results of student assessment of the module products obtained can represent all students in the field who have various abilities. This sample selection technique is called purposive sampling. Purposive sampling technique is a sampling technique with certain considerations (Sugiyono, 2012). The results of the limited trial of the module are shown in Table 2 and Table 3 .

Table 1. Summary of Expert Validation

\begin{tabular}{lcccc}
\hline $\begin{array}{c}\text { Validatio } \\
\mathbf{n}\end{array}$ & $\begin{array}{c}\text { Averag } \\
\mathbf{e}\end{array}$ & $\begin{array}{c}\text { Percentag } \\
\mathbf{e}(\boldsymbol{\%})\end{array}$ & $\begin{array}{c}\text { Catego } \\
\text { ry }\end{array}$ & Criteria \\
\hline $\begin{array}{l}\text { Material } \\
\text { Expert }\end{array}$ & 3,68 & 92,18 & Valid & Appropriate \\
Learning & 3,56 & 88,89 & Valid & Appropriate \\
Expert & & & & \\
Linguist & 3,90 & 97,50 & Valid & Appropriate \\
Media & 3,81 & 95,37 & Valid & Appropriate \\
Expert & & & & \\
Practitione & 3,73 & 93,27 & Valid & Appropriate \\
r & & & & \\
Peers & 3,42 & 85,54 & Valid & Appropriate \\
\hline
\end{tabular}

Table 2. Module Evaluation Result by Teachers

\begin{tabular}{llcc}
\hline Teachers & \multicolumn{1}{c}{ Aspect } & $\begin{array}{c}\text { Avera } \\
\text { ge (\%) }\end{array}$ & Qualification \\
\hline \multirow{2}{*}{2} & Presentation & 95,00 & Very Well \\
teachers & Content & 87,50 & Very Well \\
& Language/Readability & 91,07 & Very Well \\
\hline & Average & 91,19 & Very Well \\
\hline
\end{tabular}

The results of the module assessment by the science teacher showed an average score of $91.19 \%$ with very well qualifications and not many revisions to the module display.

Table 3. Module Evaluation Result by Students

\begin{tabular}{llcc}
\hline $\begin{array}{c}\text { Student } \\
\text { s }\end{array}$ & \multicolumn{1}{c}{ Aspect } & $\begin{array}{c}\text { Averag } \\
\text { e (\%) }\end{array}$ & $\begin{array}{c}\text { Qualificati } \\
\text { on }\end{array}$ \\
\hline 6 & Presentation & 88,33 & Very Good \\
students & Content & 79,17 & Very Good \\
& Language/Readabil & 90,63 & Very Good \\
& ity & & \\
\hline \multicolumn{2}{l}{ Average } & 86,04 & Very Good \\
\hline
\end{tabular}

The results of the limited field test showed that according to the assessment of the small group the modules developed had very good quality with an average value of $86.04 \%$ but needed to be revised slightly. Based on the results of the module assessment by the teacher and a small group of students, the average level of achievement with qualifications is very good so it does not require in-depth revision. The decision to revise is considered based on suggestions from teachers and students on the improvement of the Scientific-based Science module on Vibration and Waves material.

The second product revision was carried out based on suggestions and input from the science teacher, namely improvements to some typos, writing formats and grammar. While the input from students in the form of images in the module is enlarged so that it is clearer. The module that has been revised according to the suggestions becomes a draft III module, then product testing is carried out on a large scale trial or operational field trial.

The large-scale trial phase uses a true experimental design type of control group pretest posttest design, meaning that the test design uses two classes, namely the control class (using textbooks commonly used in schools) and the experimental class (using scientific modules). The large-scale trial aims to determine the effectiveness of the Science-based module on wave and vibration materials to improve creative thinking skills.

This broad-scale trial involved 2 classes, namely class VIII $\mathrm{H}$ as a control class or a class that was not given a module and only used publisher books borrowed from the library, and class VIII $\mathrm{E}$ as an experimental class, namely a class that used a developed module. Each class consists of 30 students. The time allocation required for a large-scale trial is $6 \times 60$ minutes with online learning. The display of the module used is shown in Figure 1.
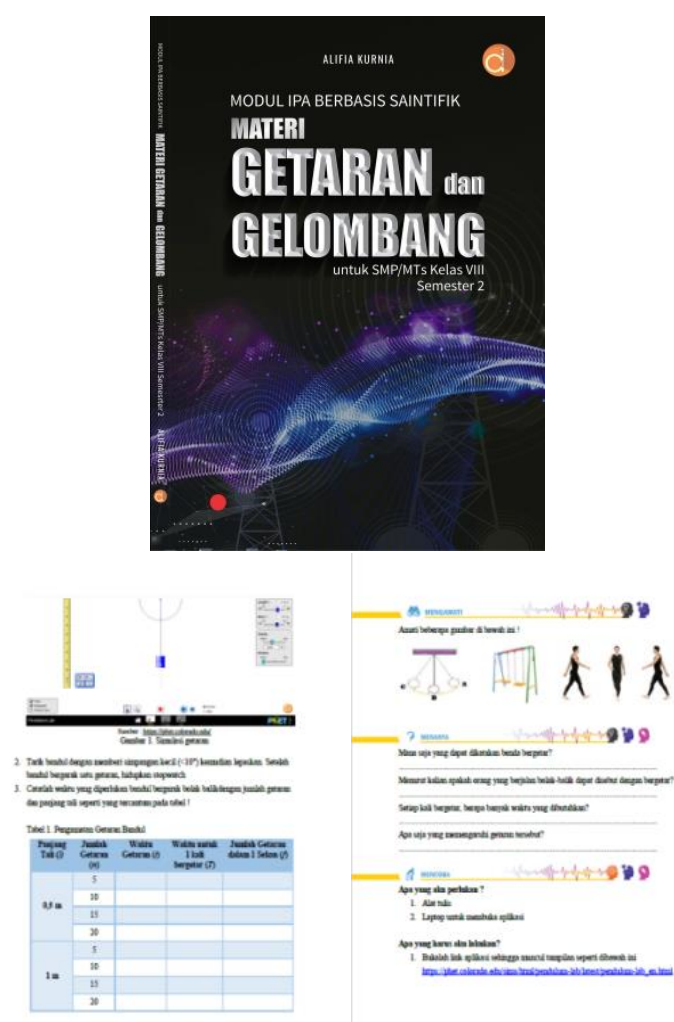

Figure 1. Science Module Content Display 
The fourth stage is disseminate, at this stage limited dissemination is carried out, namely disseminating and promoting the final product of Science-based modules on a limited basis. The distribution was confirmed to science teachers at Junior High School 7 Surakarta, Junior High School 9 Surakarta, Junior High School Widya Wacana 1 Surakarta, and Junior High School Muhammadiyah 8 Surakarta. Then the teacher fills out a response questionnaire about the module that has been developed.. Based on the results of the teacher response questionnaire analysis, the average assessment results and teachers' responses are $97.00 \%$, the range of values is included in the very well category and deserves to be used. The results of the teacher's responses are used to obtain the teacher's opinion about the feasibility response of the Scientific-based science module that has been developed using a teacher response questionnaire.

\subsection{Module Effectiveness}

The analysis to determine the equivalence of students' knowledge of the two classes before learning was tested using SPSS 20 for windows, starting with the prerequisite test, namely the normality test, homogeneity test, and the Mann-WhitneyU test using the previous daily test scores. The summary of the normality test, homogeneity test, and Mann-Whitney U test scores for the control and experimental classes can be seen in Table 4.

Table 4. Recapitulation of Test Results for Experimental and Control Classes

\begin{tabular}{llll}
\hline \multicolumn{1}{c}{ Test } & \multicolumn{2}{c}{ Result } & Conclussion \\
\hline $\begin{array}{l}\text { Normality } \\
\text { (Kolmogorov }\end{array}$ & Experiment & $0,049<$ & Abnormal \\
Smirnov) & Class & 0,005 & \\
\cline { 2 - 4 } & Control & $0,044<$ & Abnormal \\
& Class & 0,005 & \\
\hline Homogenity & Sig. $0,102>$ & & \\
(Lavene & 0,05 & & Homogen \\
Statistic) & & & $\begin{array}{l}\text { There is no } \\
\text { significant } \\
\text { Uji Mann- }\end{array}$ \\
WhitneyU & Sig. $0.583>$ & & difference \\
\hline
\end{tabular}

Based on Table 4, it is known that the data are not normally distributed even though a homogeneous distribution is met. Based on the prerequisite test, the hypothesis test used is a non-parametric statistical test, namely the Mann-WhitneyU test. Based on the assessment of the learning outcomes of the knowledge aspect obtained from the previous daily test scores, the control class and the experimental class showed the same conditions. Based on the Mann-Whitney U test, the level of sig. $0.583>0.05$ so the conclusion is that there is no significant difference in the daily test scores of the previous material from the two groups, which implies that both classes of students have equal knowledge before participating in learning activities.
Science learning using scientific-based electronic science modules is learning that is carried out based on findings obtained from a series of investigation processes. In the implementation process, students learn independently because they adjust health protocols during thenCovid-19 pandemic which requires students to study from home. In this learning process, the teacher acts as a monitor, facilitator, and evaluator in student involvement in learning (Barthlow and Watson, 2011). The teacher as a learning facilitator provides assistance to students to find facts and concepts. Concepts are not given explicitly but the teacher encourages and encourages students to be able to make conclusions and make predictions.

The next measurement was carried out after the experimental group was given learning treatment using a scientific-based electronic science module and the control group by not using a scientific-based electronic science module for six meetings conducted online on the same teaching material. Data analysis was carried out in each class, namely the experimental class and the control class. The results of the analysis of descriptive statistical data are presented in Table 5.

Based on Table 5, it can be seen that thenresults of the analysis of the normality and homogeneity tests are known that the posttest scores of students in the experimental class and control class are not normally normally distributed even though they are homogeneous. This is seen based on the significance value in the normality and homogeneity test of the control and experimental class. Therefore, the next test used the Mann-Whitney U test. Based on the MannWhitney $\mathrm{U}$ test that has been done, the results were 0.000 (Ho rejected) meaning that after the learning activities, there was a significant difference between the control and experimental classes. For a clearer comparison between the average test results of students' knowledge aspects, it can be seen in the Figure 2

Table 5. Data of Learning Outcomes on Knowledge Aspect

\begin{tabular}{lccc}
\hline \multicolumn{1}{c}{ Class } & Score & N & Average \\
\hline Control & Posttest & 30 & 69,83 \\
Experiment & Posttest & 30 & 78,83 \\
\hline
\end{tabular}




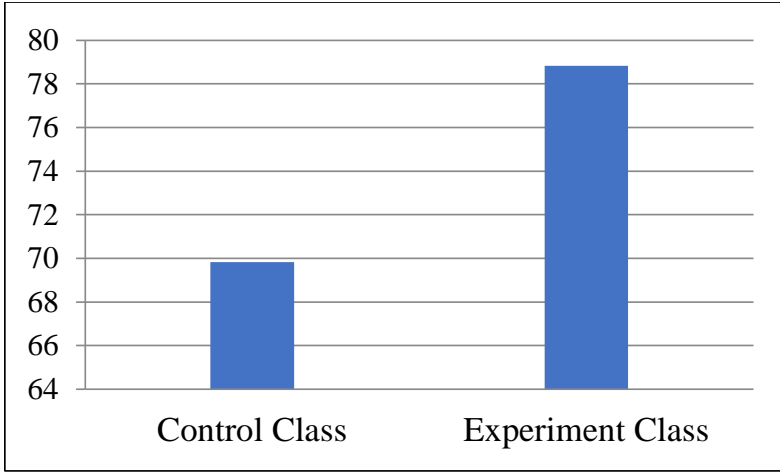

Figure 2. Comparison of Posttest Average Learning Outcomes on Knowledge Aspect in Control and Experiment Classes

Figure 2 shows the average student learning outcomes of the experimental class are higher than the control class. So it can be said that learning using the developed module is more effective in improving student learning outcomes in terms of knowledge compared to conventional learning.

The analysis used to determine the effectiveness of the Scientific-based electronic science module in the second learning can be seen from the difference in the posttest scores of students' knowledge aspects of learning outcomes between the control class and the experimental class which was tested with SPSS 20 for windows and started with a prerequisite test, namely the normality test, homogeneity test, and then the MannWhitney $U$ test, because the data is not normal even though a homogeneous distribution is met. The results of the analysis can be seen in Table 6 ..

Based on observations, in groups that apply learning using electronic modules that have been developed, there is a tendency for students to actively participate in learning and activities in the module help students find facts, concepts, principles and theories. Learning activities can provide better knowledge aspects of learning outcomes for experimental class students compared to control class students. It can be seen from the result of research at Junior High School 15 Surakarta, that the average score obtained by students in the group of students who were taught with a scientifically based electronic science module was greater than the average score obtained by the group of students who were not taught with scientific-based electronic science module. This is influenced by the scientific-based electronic science module which emphasizes more on student activities actively participating in learning, and question and answer activities so that students can find facts, concepts, principles, and theories.
Table 6. Results of Score Analysis of Learning Aspects of Knowledge

\begin{tabular}{|c|c|c|c|}
\hline & \multicolumn{2}{|c|}{ Result } & Conclussion \\
\hline \multirow[t]{2}{*}{$\begin{array}{l}\text { Normality } \\
\text { (Kolmogorov } \\
\text { Smirnov) }\end{array}$} & $\begin{array}{l}\text { Experiment } \\
\text { Class }\end{array}$ & $\begin{array}{l}0,000 \\
< \\
0,005\end{array}$ & Abnormal \\
\hline & $\begin{array}{l}\text { Control } \\
\text { Class }\end{array}$ & $\begin{array}{l}0,000 \\
< \\
0,005\end{array}$ & Abnormal \\
\hline $\begin{array}{l}\text { Homogenity } \\
\text { (Lavene } \\
\text { Statistic) }\end{array}$ & $\begin{array}{l}\text { Sig. } 0,385> \\
0,05\end{array}$ & & Homogen \\
\hline $\begin{array}{l}\text { Uji Mann- } \\
\text { WhitneyU }\end{array}$ & $\begin{array}{l}\text { Sig. } 0.000< \\
0.05\end{array}$ & & $\begin{array}{l}\text { There is a } \\
\text { significant } \\
\text { difference }\end{array}$ \\
\hline
\end{tabular}

The scientifically based electronic science module trains students to actively participate in class, so that learning is not boring and actually stimulates students to keep learning even during a pandemic through concept discovery or simulation activities while the teacher only serves as a monitor, facilitator, and evaluator. In addition, with the implementation of this module, students become more critical, as evidenced by actively asking questions when carrying out discussions and by finding their own concepts, causing students to remember the material that has been taught better.

The results of this study are in line with the results of research (Trapsilo, 2016) which shows that the scientific approach is an effective teaching approach for improving learning outcomes. This is supported (Sugeng, et al, 2016) which states that learning using a scientific approach can improve science learning outcomes for Static Fluids. In addition, research by (Arriany, 2020) shows the results that the use of online modules effectively improves student learning outcomes, as evidenced by using t-test calculations which show there are significant differences in student learning outcomes before and after using the module.

\section{CONCLUSION}

The conclusion from the discussion above is that the characteristics of the scientific-based science module have been successfully created with the aim of improving student learning outcomes in aspects of knowledge, namely through concept discovery and problem solving through the stages of make observations, ask questions, explore, analyze, and communicate. The feasibility of the Scientific-based science module to improve learning outcomes in the knowledge aspect based on expert validation is included in the very valid or appropriate category for use, while the teacher and student responses stated the developed module on the very good category or feasible to use. 
science-based science modules are proven to be effective in increasing students' knowledge seen from the results of the analysis that there is a significant difference between the experimental class and the control class. The difference is shown by the average score of students who are taught using the developed module is 78.83 and the average value of the group of students who are taught without the module is 69.83 . The result of the MannWhitney $U$ test is 0.000 . These results say that $\mathrm{H}_{0}$ is rejected and $\mathrm{H}_{1}$ is accepted, it can be concluded that there is a significant difference between two classes.

Suggestions from the results of research that have been carried out are that in order for learning with a scientific-based science module to be effective, it is necessary to provide assistance because independent learning is a new thing but must be familiarized with the conditions of the Covid-19 pandemic. Before using a scientific-based science module, teachers should understand the application of a scientific approach to the learning process so that all activities in the module can be followed and implemented effectively. The results of this research and development can be used as a reference for the next research with an emphasis on achieving 21 st century competencies.

\section{REFERENCE}

[1] Ahmed, S., Shehata, M., \& Hassanien, M. (2020). Emerging Faculty Needs for Enhancing Student Engagement on a Virtual Platform. MedEdPublish, $1-5$.

https://doi.org/https://doi.org/10.15694/mep.2020. $\underline{000075.1}$

[2] Arriany, Ike., Ibrahim N., Sukardjo M. (2020). Pengembangan Modul Online untuk Meningkatkan Hasil Belajar Ilmu Pengetahuan Sosial (IPS). Jurnal Inovasi Teknologi Pendidikan 7(1). 52-66. https://doi.org/10.21831/jitp.v7i1.23605

[3] Asmuni, A. (2020). Problematika Pembelajaran Daring di Masa Pandemi Covid-19 dan Solusi Pemecahannya. Jurnal Paedagogy, 7(4), 281. https://doi.org/10.33394/jp.v7i4.2941

[4] Azwar, S. 2007. Tes Prestasi dan Pengembangan Pengukuran Belajar. Yogyakarta: Pustaka Pelajar.

[5] Barthlow, Michele J. Dan Scott B. Watson. (2011). "The Effectiveness of Process-Oriented Guided Inquiry Learning to Reduce Alternatif Conceptions in Secondary Chemistry". Volume 114. Nomor 5 (hlm. 246- 255).

[6] Basar, A. M., Islam, P. A., Nurul, S., Cikarang, F., \& Bekasi, B. (2021). Problematika Pembelajaran Jarak Jauh Pada Masa Pandemi Covid-19 (Studi Kasus di SMPIT Nurul Fajri - Cikarang Barat -
Bekasi). 2(1), $208-218$.

https://doi.org/10.51276/edu.v2i1.112

[7] Basri, Hasan. "Kemampuan Kognitif dalam Meningkatkan Efektivitas Pembelajaran Ilmu Sosial Bagi Siswa Sekolah Dasar". Jurnal Penelitian Pendidikan, Vol. 18, No. 1, 2018.

[8] Ditasari, Rahma., Endah P., Kasmui. (2013). Pengembangan Modul Pembelajaran IPA Terpadu Berpendekatan Keterampilan Proses pada Tema Dampak Limbah Rumah Tangga Terhadap Lingkungan untuk SMP Kelas VIII. Unnes Science Education Journal 2 (2), 329-336

[9] Gozali, F., \& Lo, B. (2012). Pemanfaatan Teknologi Open Source Dalam Pengembangan Proses Belajar Jarak Jauh di Perguruan Tinggi. Jurnal Nasional Pendidikan Teknik Informatika (JANAPATI), 1(1), 47-57. https://doi.org/10.23887/janapati.v1i1.9767

[10] Hosnan. (2014). Pendekatan Saintifik dan Kontekstual dalam Pembelajaran Abad 21. Bogor : Ghalia Indonesia.

[11] Idrus, Irham., Irwadi A., Rio K. (2020). Pendekatan Saintifik untuk Meningkatkan Aktivitas dan Hasil Belajar IPA Siswa SMP. Jurnal Pendidikan dan Pembelajaran Biologi 4 (2)I, 139-145.

[12] Imansari, N., \& Sunaryantiningsih, I. (2017). Pengaruh Penggunaan E-Modul Interaktif Terhadap Hasil Belajar Mahasiswa pada Materi Kesehatan dan Keselamatan Kerja. VOLT : Jurnal Ilmiah Pendidikan Teknik Elektro, 2(1), 11. https://doi.org/10.30870/volt.v2i1.1478

[13] Kusuma, J. W., \& Hamidah. (2020). Platform Whatsapp Group Dan Webinar Zoom Dalam Pembelajaran Jarak Jauh Pada Masa Pandemik Covid 19. Jurnal Ilmiah Pendidikan Matematika Volume, 5(1).

[14] Malyana, A. (2020). Pelaksanaan Pembelajaran Daring Dan Luring Dengan Metode Bimbingan Berkelanjutan Pada Guru Sekolah Dasar Di Teluk Betung Utara Bandar Lampung. Pedagogia: Jurnal Ilmiah Pendidikan Dasar Indonesia, 2(1), 67-76. https://doi.org/10.52217/pedagogia.v2i1.640.

[15] Mustaji, 2008. Penyusunan Modul, Jakarta; Rajawali Perss

[16] Mustika, Z. (2015). Urgenitas Media Dalam Mendukung Proses Pembelajaran Yang Kondusif. CIRCUIT: Jurnal Ilmiah Pendidikan Teknik Elektro, 1(1), 60-73. https://doi.org/10.22373/crc.v1i1.311. 
[17] Nakayama, M, \& Yamamoto. (2006). Investigating the impact of learner characteristics on blended learning among Japanese Students. Proceedings of the International Conference on E-Learning, ICEL, 2006-Janua(3), 361-370.

[18] Putri, Ni Kadek Rossita Cahyani, dkk. (2021). EModul Interaktif pada Muatan IPA Subtema 1 Tema 8 Kelas V Sekolah Dasar. Jurnal Penelitian dan Pengembangan Pendidikan, 5(2), 175-182.

[19] Santosa, P. I. (2011). No Model Konseptual Pemanfaatan Teori Flow Dalam eLearning. Jurnal Nasional Pendidikan Teknik Informatika, 1(1), 2428.

https://doi.org/http://dx.doi.org/10.23887/janapati. $\underline{\mathrm{v} 1 \mathrm{i} 1.9756}$

[20] Siswono T Y E. (2008). Model Pembelajaran Matematika Berbasis Pengajuan dan Pemecahan Masalah untuk Meningkatkan Kemampuan Berpikir Kreatif (Surabaya: Universitas Negeri Surabaya)
[21] Sugiyono. 2013. Metode Penelitian Pendidikan Pendekatan Kuantitatif, Kualitatif, dan $R \& D$. Bandung: Alfabeta

[22] Sun, L., Tang, Y., \& Zuo, W. (2020). Coronavirus pushes education online. Nature Materials, 20200205. https://doi.org/10.1038/s41563-020$\underline{0678-8}$

[23] Suwasono. (2013). Pengembangan E-Modul Online Elektronika Analog Pada Pendidikan Jarak Jauh. Teknologi Dan Kejuruan, 36(1), 51-62. https://doi.org/10.17977/tk.v36i1.4070.

[24] Trapsilo, Budi., Roesminingsih., Subroto, WT. (2016). Penerapan Pendekatan Saintifik untuk Meningkatkan Hasil Belajar Siswa pada Mata Pelajaran IPS Materi Perkembangan Teknologi Kelas IV SDN Kluwih 02 Bandarbatang. Jurnal Kajian Pendidikan dan Hasil Penelitian 2(1). 112117

[25] Zainiyati, Husniyatus Salamah. 2017. Pengembangan Media Pembelajaran Berbasis ICT (Konsep dan Aplikasi pada Pembelajaran Pendidikan Agama Islam). Jakarta: Kencana. 